\title{
Development of Standards for Hydrogen Safety
}

\author{
Yanmei Yang ${ }^{1,}$, Haigang X $u^{2}$, Ling $\operatorname{Lin}^{1}$, Wei Bao ${ }^{1,3}$, Bangqiang Zhang ${ }^{3}$, Bin $\mathrm{Ai}^{3}$ \\ ${ }^{1}$ China National Institute of Standardization, 100191 Beijing, China \\ ${ }^{2}$ Shanghai Institute of Space Propulsion, 201112 Shanghai, China \\ ${ }^{3}$ Foshan Green Development Innovation Research Institute, 528200 Guangdong, China
}

\begin{abstract}
Safety standards are foundation for the deployment and development of hydrogen industry. In this paper, standards for hydrogen safety published by ISO, IEC and SAC are summarized and discussed. Standard framework of hydrogen safety is analysed. ISO standards are mainly focused on general safety standards and safety standards of hydrogen production. IEC standards are mainly focused on safety standards of fuel cell and fuel cell applications. China has basically established a safety standard framework for hydrogen industry. Safety standards for different stage of hydrogen industry are discussed and analysed. Suggestions of safety standards preparation for China are proposed.
\end{abstract}

\section{Introduction}

In recent years, hydrogen industry is booming in China, Europe, Japan, South Korea and USA under the development of technologies and the pressure of environment protection [1, 2]. Since 2016, development of hydrogen industry has sped up in China. Local governments and enterprises actively promote the deployment of hydrogen applications, such as hydrogen fuel cell vehicles, stationary power, and backup power. From 2016 to 2019 , total sales of hydrogen fuel cell vehicles are 6450 in China, including buses and trucks. Total number of hydrogen fuelling stations in operation is 41 in China, including 5 oil and hydrogen combined fuelling stations [3]. Hydrogen industry clusters are formed in Beijing-Tianjin-Hebei region, Pearl River delta and Yangtze River delta, and are affecting the surrounding areas.

Compared to hydrocarbons, hydrogen has wide limits of flammability and detonability, ignition and detonation energies low, non-luminous flame, very buoyant and diffusive. Besides, hydrogen over time can migrate through materials. When the metal surface is exposed to ionized hydrogen, hydrogen embrittlement usually occurs $[4,5]$. Safety is the foundation of developing hydrogen industry. In this paper, safety standards for hydrogen industry are discussed and analysed.

\section{Standardization technical committees}

\subsection{ISO technical committees}

Technical Committee of Hydrogen Technologies (ISO/TC 197) and subcommittee of Electrically Propelled Vehicles of Road Vehicles (ISO/TC 22/SC 37) are two main ISO technical committees focused on standards of hydrogen and fuel cell vehicles. ISO/TC 197 is specialized in standardization in the field of systems and devices for the production, storage, transport, measurement and use of hydrogen. ISO/TC 22/SC 37 is specialized in aspects of electrically propelled road vehicles, electric propulsion systems, related components and their vehicle integration.

\subsection{IEC technical committees}

Technical Committee of Fuel Cell Technologies (IEC/TC 105) is focused on developing standards of fuel cell technologies for all fuel cell (FC) types and various associated applications, including stationary FC power systems for distributed power generators and combined heat and power systems, FCs for transportation, auxiliary power units, portable FC power systems, micro FC power systems [6], etc..

\subsection{Chinese standardization technical committees}

National Standardization Technical Committee of Hydrogen Energy (SAC/TC 309), Road Vehicles (SAC/TC 114), Fuel Cell and Flow Battery (SAC/TC 342), and High Pressure Vehicle Fuel Tanks (SAC/TC $31 / \mathrm{SC} 8$ ) are the main technical committees devote to develop national hydrogen standards.

\section{Hydrogen safety standards}

Safety standards are essentially important in hydrogen industry. As is shown in Figure 1, hydrogen safety standards include general safety standards, safety standards of hydrogen production, storage and

\footnotetext{
* Corresponding author: yangym@cnis.ac.cn
} 
transportation, fuelling, fuel cell and fuel cell applications.

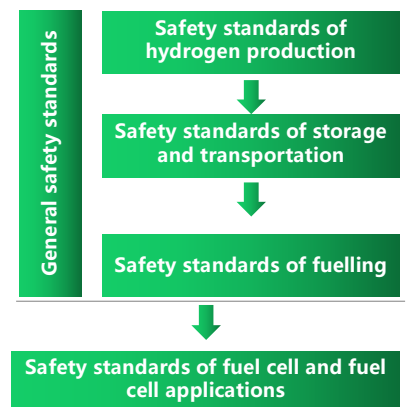

Fig. 1. Framework of Hydrogen Safety Standards

\subsection{ISO standards}

ISO safety standards for hydrogen are listed in Table 1. ISO/TR 15916 provides guidelines for the use of hydrogen in its gaseous and liquid forms as well as its storage in either of these or other forms (hydrides). It defines the basic safety concerns, hazards and risks, and describes the properties of hydrogen that are relevant to safety. ISO $16110-1$ is a product safety standards which provides significant hazards, hazardous situations and events relevant to hydrogen generators, with the exception of those associated with environmental compatibility (installation conditions), when they are used as intended and under the conditions foreseen by the manufacturer. It is applicable to stationary hydrogen generators intended for indoor and outdoor commercial, industrial, light industrial and residential use. ISO/TS 19883 identifies safety measures and applicable design features that are used in the design, commissioning, and operation of pressure swing adsorption (PSA) systems for hydrogen separation and purification. It applies to hydrogen pressure swing adsorption systems that process all kinds of impure hydrogen streams as feed. It also applies to small-scale PSA hydrogen system installed within containers, which allowed by local regulations. ISO 23273 specifies the essential requirements for fuel cell vehicles with respect to the protection of persons and the environment inside and outside the vehicle against hydrogen-related hazards. It applies only to such fuel cell vehicles where compressed hydrogen is used as fuel for the fuel cell system.

Table 1. ISO standards for hydrogen safety

\begin{tabular}{|c|l|l|}
\hline No. & Number of standards & \multicolumn{1}{|c|}{ Name of standards } \\
\hline 1 & ISO/TR 15916:2015 & $\begin{array}{l}\text { Basic considerations for the } \\
\text { safety of hydrogen systems }\end{array}$ \\
\hline 2 & ISO 16110-1:2007 & $\begin{array}{l}\text { Hydrogen generators using } \\
\text { fuel processing technologies -- } \\
\text { Part 1: Safety }\end{array}$ \\
\hline 3 & ISO/TS 19883:2017 & $\begin{array}{l}\text { Safety of pressure swing } \\
\text { adsorption systems for } \\
\text { hydrogen separation and } \\
\text { purification }\end{array}$ \\
\hline 4 & ISO 23273:2013 & Fuel cell road vehicles - Safety \\
\hline
\end{tabular}

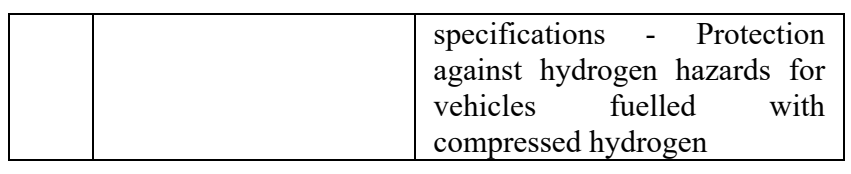

\subsection{IEC standards}

IEC safety standards for hydrogen are listed in Table 2 . IEC 62282-2-100 provides safety related requirements for construction, operation under normal and abnormal conditions and the testing of fuel cell modules. It deals with conditions that can yield hazards to persons and cause damage outside the fuel cell modules. IEC 622823-100 applies to stationary packaged, self-contained fuel cell power systems or fuel cell power systems comprised of factory matched packages of integrated systems which generate electricity through electrochemical reactions. It is applicable to stationary fuel cell power systems intended for indoor and outdoor commercial, industrial and residential use in non-hazardous areas. IEC 62282-4101 provides safety requirements for fuel cell power systems intended to be used in electrically powered industrial trucks. It is limited to electrically powered industrial trucks and is applicable to material-handling equipment, e.g. forklifts. It applies to gaseous hydrogenfuelled fuel cell power systems and direct methanol fuel cell power systems for electrically powered industrial trucks. IEC 62282-5-100 covers construction, marking and test requirements for portable fuel cell power systems. It applies to AC and DC type portable fuel cell power systems, with a rated output voltage not exceeding $600 \mathrm{~V} \mathrm{AC}$, or $850 \mathrm{~V} \mathrm{DC}$ for indoor and outdoor use. IEC 62282-6-100 covers micro fuel cell power systems, micro fuel cell power units and fuel cartridges that are wearable or easily carried by hand, providing d.c. outputs that do not exceed $60 \mathrm{~V}$ d.c. and power outputs that do not exceed $240 \mathrm{VA}$. IEC/PAS 62282-6-150 covers micro fuel cell power systems using hydrogen produced from the reaction of an aqueous solution with solid UN Devision 4.3 (water-reactive) compounds in indirect PEM fuel cell systems that are wearable or easily carried by hand, providing d.c. outputs that do not exceed $60 \mathrm{~V}$ d.c. and power outputs that do not exceed 240 VA.

Table 2. IEC standards for hydrogen safety

\begin{tabular}{|c|c|l|}
\hline No. & Number of standards & Name of standards \\
\hline 1 & IEC 62282-2-100:2020 & $\begin{array}{l}\text { Fuel cell technologies - } \\
\text { Part 2-100: Fuel cell } \\
\text { modules - Safety }\end{array}$ \\
\hline 2 & IEC 62282-3-100:2019 & $\begin{array}{l}\text { Fuel cell technologies - } \\
\text { Part 3-100: Stationary } \\
\text { fuel cell power systems } \\
\text { - Safety }\end{array}$ \\
\hline 4 & IEC 62282-4-101:2014 & $\begin{array}{l}\text { Fuel cell technologies - } \\
\text { Part 4-101: Fuel cell } \\
\text { power systems for } \\
\text { propulsion other than } \\
\text { road vehicles and } \\
\text { auxiliary power units } \\
\text { (APU) - Safety of }\end{array}$ \\
\hline
\end{tabular}




\begin{tabular}{|c|l|l|}
\hline & & $\begin{array}{l}\text { electrically powered } \\
\text { industrial trucks }\end{array}$ \\
\hline 5 & IEC 62282-5-100:2018 & $\begin{array}{l}\text { Fuel cell technologies - } \\
\text { Part 5-100: Portable } \\
\text { fuel cell power systems } \\
\text { - Safety }\end{array}$ \\
\hline 6 & IEC 62282-6-100:2010 & $\begin{array}{l}\text { Fuel cell technologies - } \\
\text { Part 6-100: Micro fuel } \\
\text { cell power systems - } \\
\text { Safety }\end{array}$ \\
\hline 7 & & $\begin{array}{l}\text { Fuel cell technologies - } \\
\text { Part 6-150: Micro fuel } \\
\text { cell power systems - } \\
\text { Safety - Water reactive } \\
\text { (UN Devision 4.3) } \\
\text { compounds in indirect } \\
\text { PEM fuel cells }\end{array}$ \\
\hline
\end{tabular}

\subsection{Chinese National standards}

Chinese national standards (GB standards) for hydrogen safety are listed in Table 3. GB 4962-2008 provides the safety technical requirements for the use, replacement, storage, compression, fuelling, discharge, fire control, emergency treatment, and safety protection for gaseous hydrogen. It applies to the ground workplaces after production of gaseous hydrogen, but not applies to liquid hydrogen, gaseous hydrogen on water, hydrogen for aviation and on-board hydrogen supply system. GB/T 23751.1-2009 is modified adopted from IEC 62282-6100:2007. GB/T 24549-2009 provides the safety requirements of fuel system, fuel cell system, power circuit system, function, fault protection and collision of fuel cell electric vehicles. It applies to fuel cell electric vehicles using gaseous hydrogen. GB/T 27748.1-2017 is identical adopted from IEC 62282-3-100:2012. GB/T 29729-2013 specifies the basic categories of hydrogen system (hydrogen production system, storage system and transportation system), basic characteristics of hydrogen, risk factors of hydrogen system and basic requirements of risk control. It is applicable to the design and use of hydrogen production, storage and transportation system. GB/T 30084-2013 is identically adopted from IEC 62282-5-1:2012. GB/T 31036-2014 covers terms, safety requirements and protective measures, type tests, routine tests, identification, label and packaging related to the proton exchange membrane fuel cell backup power system (PEMFC). This standard applies to proton exchange membrane fuel cell backup power systems, including PEMFC backup power systems that provide $\mathrm{AC}$ or DC current, and PEMFC backup power systems that use hydrogen and air as reaction gases. GB/T 31037.1-2014 specifies the safety requirements and safety protection measures related to the structure, identification and performance test of fuel cell power generation system for lifting vehicles. It is applicable to proton exchange membrane fuel cell industrial lifting vehicles which use gaseous hydrogen as fuel and air as oxidant. It only considers the risk situations that may cause injury to persons, objects or environment outside the fuel cell power generation system, and proposes safety measures for such dangerous situations. GB/T 31139-2014 specifies the terms, safety technical requirements, operation safety management, transportation and long-term parking requirements of mobile hydrogen refuelling facilities. It is applicable to mobile hydrogen refuelling facilities with fuelling pressure ranging from $15 \mathrm{MPa}$ to $70 \mathrm{MPa}$. GB/T 33983.12017 only considers the dangerous situations that may cause harm to public safety, human health or environment outside the direct methanol fuel cell system. It includes the safety requirements for dangerous situations, excluding the safety measures that may cause damage to the system itself. GB/T 34539-2017 specifies the basic safety requirements of hydrogen-oxygen generator, environmental safety requirements, gas supply system, electrical device, safety protection device, trial operation, operation and maintenance, emergency treatment and other requirements. It is applicable to hydrogen-oxygen generator and hydrogen oxygen mixed pipelines with working pressure $\leqslant 0.2 \mathrm{MPa}$ and $\mathrm{PV} \leqslant$ 8.0MPa • L. GB/T 34544-2017 specifies the safety test conditions and test methods of low-pressure hydrogen storage device for small fuel cell vehicles, which is applicable to the low-pressure hydrogen storage device for small fuel cell vehicles with internal volume not greater than $3 \mathrm{~L}$, maximum temperature rise pressure not greater than $25 \mathrm{MPa}$, working temperature not lower than - $40{ }^{\circ} \mathrm{C}$ and not higher than $65{ }^{\circ} \mathrm{C}$. GB/T 34583-2017 specifies safety technical requirements for hydrogen storage devices used in hydrogen fuelling station. It is applicable to stationary gaseous hydrogen storage device and seamless tube type gaseous hydrogen storage cylinders used in hydrogen fuelling station filled with high-pressure hydrogen, and the design pressure is not more than $100 \mathrm{MPa}$, and the service temperature is not lower than $-40{ }^{\circ} \mathrm{C}$ and not higher than $60{ }^{\circ} \mathrm{C}$. GB/T 34584-2017 specifies the safety technical requirements for hydrogen transportation, hydrogen production, hydrogen storage, compression, fuelling, safety and fire protection of hydrogen fuelling station. It is applicable to the hydrogen fuelling station with various hydrogen supply methods, and also applicable to hydrogen and gasoline joint fuelling stations, hydrogen and natural gas joint fuelling stations, hydrogen fuelling and charging stations, etc. GB/T 36288-2018 specifies the safety requirements of hydrogen gas, electrical equipment, and mechanical structure for fuel cell stacks used in fuel cell electric vehicles. It is applicable to the protection of human body and harm outside the stacks, not include the protection of fuel cell stacks. GB/T 37563-2019 specifies the dangerous and harmful factors, basic safety requirements and requirements for environmental conditions, system components, operation and maintenance, operators and emergency treatment of pressurized water electrolysis system. It is applicable to alkaline water electrolysis system and proton exchange membrane water electrolysis system with working pressure $\geqslant 0.3 \mathrm{MPa}$ and $\leqslant 5.0 \mathrm{MPa}$. GB/Z 34541-2017 specifies the management procedures related to the safe operation, personnel, equipment safety, gas quality, production operation, supervision and inspection, and emergency plan of hydrogen fuelling facilities of hydrogen vehicles. It is applicable to the safe operation 
management of facilities involved in providing hydrogen fuelling services for hydrogen vehicles by using highpressure gaseous hydrogen, liquid hydrogen and hydrogen mixed gas as fuel.

Table 3. Chinese national standards for hydrogen safety

\begin{tabular}{|c|c|c|}
\hline No. & Number of standards & Name of standards \\
\hline 1 & GB 4962-2008 & $\begin{array}{l}\text { Technical safety regulation for } \\
\text { gaseous hydrogen use }\end{array}$ \\
\hline 2 & GB/T 23751.1-2009 & $\begin{array}{l}\text { Micro fuel cell power systems } \\
\text { - Part 1: Safety }\end{array}$ \\
\hline 3 & GB/T 24549-2009 & $\begin{array}{l}\text { Fuel cell electric vehicles - } \\
\text { Safety requirements }\end{array}$ \\
\hline 4 & GB/T 27748.1-2017 & $\begin{array}{l}\text { Stationary fuel cell power } \\
\text { systems - Part 1:safety }\end{array}$ \\
\hline 5 & GB/T 29729-2013 & $\begin{array}{l}\text { Essential requirements for the } \\
\text { safety of hydrogen systems }\end{array}$ \\
\hline 6 & GB/T 30084-2013 & $\begin{array}{l}\text { Portable fuel cell power } \\
\text { system-safety }\end{array}$ \\
\hline 7 & GB/T 31036-2014 & $\begin{array}{l}\text { Proton exchange membrane } \\
\text { fuel cell backup power system } \\
\text { - Safety }\end{array}$ \\
\hline 8 & GB/T 31037.1-2014 & $\begin{array}{l}\text { Fuel cell power system used } \\
\text { for industrial lift truck } \\
\text { applications - Part 1: Safety }\end{array}$ \\
\hline 9 & GB/T 31139-2014 & $\begin{array}{l}\text { Safety technical regulations } \\
\text { for mobile hydrogen refuelling } \\
\text { facility }\end{array}$ \\
\hline 10 & GB/T 33983.1-2017 & $\begin{array}{l}\text { Direct methanol fuel cell } \\
\text { system - Part 1: Safety }\end{array}$ \\
\hline 11 & GB/T 34539-2017 & $\begin{array}{l}\text { Safety requirements on } \\
\text { hydrogen-oxygen generator }\end{array}$ \\
\hline 12 & GB/T 34544-2017 & $\begin{array}{l}\text { Safety test methods for } \\
\text { onboard low pressure } \\
\text { hydrogen storage devices for } \\
\text { small fuel cell vehicles }\end{array}$ \\
\hline 13 & GB/T 34583-2017 & $\begin{array}{l}\text { Safety technical requirements } \\
\text { for hydrogen storage devices } \\
\text { used in hydrogen fuelling } \\
\text { station }\end{array}$ \\
\hline 14 & GB/T 34584-2017 & $\begin{array}{l}\text { Safety technical regulations } \\
\text { for hydrogen refuelling station }\end{array}$ \\
\hline 15 & GB/T 36288-2018 & $\begin{array}{l}\text { Fuel cell electric vehicles - } \\
\text { Safety requirement of fuel cell } \\
\text { stack }\end{array}$ \\
\hline 16 & GB/T 37563-2019 & $\begin{array}{llr}\text { Safety } & \text { requirements } & \text { for } \\
\text { pressurized } & \text { water } & \text { electrolysis } \\
\text { system } & \text { for } & \text { hydrogen } \\
\text { production } & & \\
\end{array}$ \\
\hline 17 & GB/Z 34541-2017 & $\begin{array}{l}\text { Safety operation management } \\
\text { regulation for hydrogen } \\
\text { fuelling facilities of hydrogen } \\
\text { vehicles }\end{array}$ \\
\hline
\end{tabular}

\subsection{Safety standards}

As is shown in Figure 2, there are 1 ISO general safety standards, 2 ISO safety standards of hydrogen production, 1 ISO safety standards of fuel cell application, and 6 IEC safety standards of fuel cell and fuel cell applications. There are 2 GB general safety standards, 2 GB safety standards of hydrogen production, 2 GB safety standards of storage and transportation, and
8 GB safety standards of fuel cell and fuel cell applications.

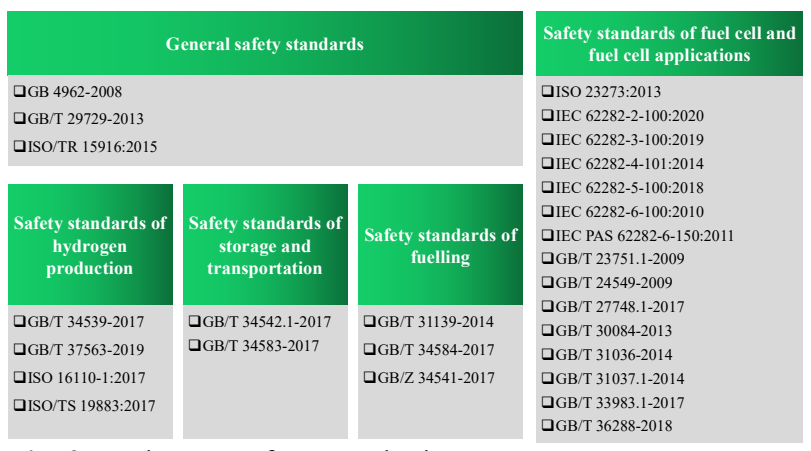

Fig. 2. Hydrogen Safety Standards

\section{Conclusions}

Safety standards are foundation for the deployment and development of hydrogen industry. ISO standards are mainly focused on general safety standards and safety standards of hydrogen production. IEC standards are mainly focused on safety standards of fuel cell and fuel cell applications. China has basically established a safety standard framework for hydrogen industry. There are some GB standards for safety of hydrogen production, storage and transportation, fuelling, fuel cell, and fuel cell applications. Based on the demands of industry, safety standards of storage and transportation, fuelling, fuel cell applications need to be prepared in pace with development of technologies and industry.

\section{References}

1. Hydrogen Council. Hydrogen scaling up - a sustainable pathway for the global energy transition (2017)

2. J. D. Holladay, J. Hu, D. L. King, Y. Wang, Catalysis Today 13917 (2009)

3. China Association of Automobile Manufactures, Report of fuel cell vehicle industry (2019)

4. R. Wurster, Compendium of Hydrogen Energy 4, 195 (2016)

A. O. Bique, L. K. Maia, F. L. Mantia, D. Manca, E. Zondervan, Computers \& Chemical Engineering 129 (2019)

5. Y. Yang, G. Wang, S. Zhang, L. Zhang, L. Lin, ICAEER 2019 